\title{
Elastofibroma Dorsi: Positron Emission Tomography/Computed Tomography Perspective
}

\author{
Elastofibroma Dorsi, Pozitron Emisyon Tomografi/Bilgisayarlı Tomografi Perspektifi
}

\author{
(D) Tamer Aksoy \\ İstanbul Training and Research Hospital, Clinic of Nuclear Medicine, İstanbul, Turkey
}

\begin{abstract}
Introduction: Elastofibroma dorsi (ED) is a rare, benign and slowly growing connective tissue tumor that is frequently observed in the subscapular region in elderly people. It can be detected with various imaging modalities, such as computed tomography (CT), magnetic resonance imaging, ultrasonography and positron emission tomography (PET). In this retrospective study, the clinical features of EDs detected in PET/CT examinations performed for malignant or nonmalignant causes were evaluated.
\end{abstract}

Methods: In this retrospective study, PET/CT examinations performed between May 2014 and December 2017 in a single institution for oncological and non-oncological diseases were evaluated retrospectively. Anatomical dimensions of the lesions were evaluated on axial CT sections. The metabolic activities or receptor expression status of the lesions were

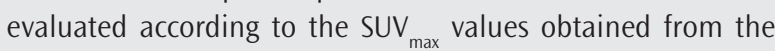
region of interests drawn on the lesions detected in PET scans.

Results: A total of 7300 PET/CT reports were searched for term "ED" and the images of patients with ED were re-evaluated. ED was detected in 174 scans of 131 patients (97 female and 34 male; mean age: $62.13 \pm 8.6$ years). The prevalence of ED was $1.79 \%$. Bilateral ED was detected in 116 patients (88.5\%) and 15 patients (11.5\%) had unilateral ED. The mean diameter was $2.6 \times 4.9 \pm 1.1 \times 1.9 \mathrm{~cm}$, and mean $\mathrm{SUV}_{\max }$ value was $2.46 \pm 0.74$. There were statistically significant differences regarding SUV values and measured dimensions ( $p=0.001$ ).

Conclusion: In this study, the prevalence and demographic patterns of ED were demonstrated with F-18 fluorodeoxyglucose and Ga-68 DOTATATE PET-CT. Knowledge of the distribution and uptake patterns of PET agents and their physiological uptake sites will prevent unnecessary procedures and interventions.

Keywords: Elastofibroma dorsi, PET/CT, F-18 FDG, Ga-68 DOTATATE

\section{ÖZ}

Amaç: Elastofibroma dorsi (ED), nadir görülen ve yavaş büyüyen bir bağ dokusu tümörü olup, sıklıkla yașlı hastalarda subskapüler bölgede gözlenmektedir. Bilgisayarlı tomografi (BT), manyetik rezonans görüntüleme, ultrasonografi ve pozitron emisyon tomografi (PET) gibi çeșitli görüntüleme yöntemleri ile tanı konulabilmektedir. Bu retrospektif çalıșmada malign veya malign olmayan sebeplerden ötürü uygulanan PET/BT incelemelerinde saptanan ED'lerin klinik özellikleri değerlendiriliștir.

Yöntemler: Bu çalışmada Mayıs 2014-Aralık 2017 tarihleri arasında tek bir merkezde onkolojik veya onkolojik olmayan hastalıklar nedeniyle gerçekleștirilen PET/BT incelemeleri retrospektif olarak değerlendirilmiştir. Lezyonların anatomik boyutları BT incelemelerindeki aksiyel kesitler üzerinden değerlendirilmiştir. Lezyonların metabolik aktiviteleri veya reseptör ekspresyon durumları PET incelemesinde saptanan lezyonlar üzerine çizilen ilgi alanlarından elde edilen SUV değerleri ile hesaplanmıştır.

Bulgular: Toplamda 7300 PET raporu “ED” açısından taranmıș ve ED saptanan hastaların görüntüleri tekrar değerlendirilmiştir. Yüz otuz bir hastaya ait 174 incelemede (97 kadın, 34 erkek, ortalama yaş: $62.13 \pm 8.6)$ ED saptandı. Prevelans \%1,79 olarak saptandı. Yüz on altı hastada $(\% 88,5)$ bilateral olarak ED saptanmış iken; sağda daha sık olmak üzere 15 hastada tek

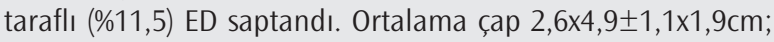
ortalama SUV $_{\text {max }}$ değeri ise $2,46 \pm 0,74$ olarak hesaplandı. SUV değerleri ile ölçülen boyutlar arasında istatistiksel olarak anlamlı farklılık $(p=0,001)$ saptandı.

Sonuç: Bu çalışmada F-18 florodeoksiglikoz ve Ga-68 DOTATATE PET/BT incelemelerindeki ED'nin prevelansı ve demografik özellikleri belirtilmiștir. Çeșitli PET ajanlarının tutulum özelliklerinin ve dağılım sahalarının bilinmesi, gereksiz tetkiklerin ve girişimlerin önüne geçecektir.

Anahtar Kelimeler: Elastofibroma Dorsi, PET/BT, F-18 FDG, Ga68 DOTATATE 


\section{Introduction}

Elastofibroma dorsi (ED) is a rare, benign and slowly growing connective tissue tumor that occurs most often in the subscapular area in the elderly, especially in women. It was first described by Jarvi and Saxen (1) in 1961. ED is described as the accumulation of abnormal elastic fibers that cause a pseudo tumor and is generally regarded as a reactive process due to recurrent micro-traumas (2-4). This lesion classically occurs in the subscapular region, deep to serratus anterior and latissimus dorsi muscles. It is mostly bilateral in up to $80 \%$ of cases. When unilateral, it is reported more frequently on the right side than the left (4). Less common locations of ED are ischial tuberosity, olecranon or elsewhere along the thoracic wall (5-8). No treatment is required unless the patient is symptomatic. If symptomatic, the lesion can be surgically excised.

Although the prevalence of ED has been reported up to $17 \%$ in some autopsy series (3), incidental detection rate of these lesions was reported less than this number in chest CT (2\%) and positron emission tomography/computed tomography (PET/CT) (1.7\%) studies (9-12). Poorly defined, soft tissue density lesion with internal fat striations at $C T$ in the subscapular region is considered diagnostic for ED in most cases. Similar to $\mathrm{CT}$, magnetic resonance imaging (MRI) findings may demonstrate a fibro fatty lesion with the fibrous tissue appearing isointense with skeletal muscle on T1- and T2-weighted imaging. Various studies and case reports can be found in the literature defining the role of PET/CT $(10,11,13-16)$.

The aim of this study is to investigate the prevalence and uptake patterns of different PET radiopharmaceuticals in Turkish population.

\section{Methods}

\section{Patients and Methods}

In this retrospective study, the reports of $7300 \mathrm{PET} / \mathrm{CT}$ examinations performed in a single institution and reported by a single nuclear medicine specialist between May 2014 and December 2017 were retrospectively searched for the term "ED". PET/CT images of patients in the search result were re-evaluated.

\section{Positron Emission Tomography/Computed Tomography İmaging}

All PET scans were performed for oncological and non-oncological purposes. Oncological PET scans were performed with F-18 Fluorodeoxyglucose (FDG), Ga-68 DOTATATE [a peptide with somatostatin receptor (SSTR) affinity] or Ga-68 prostate specific membrane antigen (PSMA). Non-oncological PET scans included benign diseases like sarcoidosis, fewer of unknown origin or cardiac viability evaluation etc.

All patients were scanned using the same PET/CT device (Siemens Biograph mCT 20 ultra HD, Hoffmann Estates, Illinois, USA) according to the national or international guidelines. For oncological and nononcological PET/CT scans other than cardiac viability, PET/CT scans were performed 45-60 minutes after the IV injection of 3.7-5.2 MBq/ kg F-18 FDG or 1.8-2.2 MBq/kg Ga-68 DOTATATE. After acquisition of a scout image, CT imaging for PET/CT was performed using a multidetector scanner with 20 slices, at 80-140 kV, 20-266 mAs, 0.8 pitch and $512 \times 512$ matrix [personalized settings determined by automatic exposure control system; automatically defined by the software used by manufacturer (CareDose 4D) depending on the patient and region assessed]. CT imaging was performed between vertex and upper-thigh in craniocaudal direction with $3 \mathrm{~mm}$ of slice thickness and 0.5 seconds of rotation time. Then, PET imaging was performed in the same range through craniocaudal direction at 8 to 9 bed positions, 1.5 minutes for each PET bed. Ultra HD images were acquired using Time of flight (TOF) + True X algorithm for Siemens mCT 20 ultra HD London Symphony Orchestra PET-CT at iteration 2 and subset 16 values for reconstruction. For cardiac viability PET/CT scan, 25-50 mg of oral glucose loading and supplemental insulin administration was performed after 6 hours of fasting. Then, 3.7-5.2 MBq/kg F-18 FDG was injected intravenously. A non-enhanced low-dose CT was acquired for attenuation correction. The subsequent PET scan was acquired in the 3D cardiac GATED mode from the level of the heart (1 bed position, 10 min per bed position) without repositioning the patient on the table. Patients were allowed to breathe normally during all PET and CT acquisitions. PET images were reconstructed using $\mathrm{CT}$ data for attenuation correction. All images were evaluated with Multiseries Viewer Software (Syngo via, Siemens Healthineers).

None of the patients had surgical intervention for ED. The anatomical diameters of ED were measured from right to left and anterior to posterior on axial CT image with the longest diameter of the lesion. For visual analyses, radiopharmaceutical uptake of the lesions was divided into 3 subgroups, group 1 (no or lower uptake than the mediastinal intravascular uptake), group 2 (uptake equal or minimally higher than the mediastinal intravascular uptake) and group 3 (uptake marked higher than mediastinal intravascular uptake). Quantitative evaluation of SUV ${ }_{\text {max }}$ values was performed by gathering by the region of interest (ROI) drawn around the ED on PET scans and SUV max $_{\text {was calculated }}$ according to the following formula: maximum activity inside the ROI ( $\mathrm{MBq} / \mathrm{gr}) /$ injected radiopharmaceutical dosage ( $\mathrm{MBq} / \mathrm{kg}$ body mass). SUV $_{\text {max }}$ values gathered from F18 FDG PET scans were taken into consideration due to different uptake mechanism of Ga-68 bound peptides. The demographics of patients and characteristics of ED are given in Table 1.

\section{Table 1. Demographics of patients with elastofibroma dorsi}

\begin{tabular}{|c|c|}
\hline Patients/Scans (n) & $131 / 174$ \\
\hline Oncological F-18 FDG PET & 164 \\
\hline Non-oncological F-18 FDG PET & 6 \\
\hline F-18 FDG PET for viability & 3 \\
\hline Ga-68 DOTATATE PET & 1 \\
\hline Age (years) & $62.13 \pm 8.6$ \\
\hline Gender (F/M) & $97 \mathrm{~F} / 34 \mathrm{M}$ \\
\hline Bilateral (n \%) & $116 / 88.5 \%$ \\
\hline Unilateral (n \%) & $15 / 11.5 \%$ \\
\hline Right (n \%) & $12(9.3 \%)$ \\
\hline Left $(n \%)$ & $3(2.2 \%)$ \\
\hline $\mathrm{SUV}_{\max }($ mean $\pm \mathrm{SD})$ & $2.46 \pm 0.74(1.18-4.97)$ \\
\hline Diameters (cm) (RLXAP) (mean \pm SD) & $2.6 \times 4.9 \pm 1.1 \times 1.9 \mathrm{~cm}$ \\
\hline
\end{tabular}




\section{Statistical Analysis}

All data were expressed as mean \pm standard deviation. Pearson correlation coefficient test was used to analyze SUV ${ }_{\max }$, visual assessment and lesion size values and to compare differences between the groups. All statistical analyses were performed using the statistical package for the social sciences software (SPSS, version 15.0; SPSS Inc.) for Windows. A $p$ value of less than 0.05 was considered statistically significant. If there was no statistically significant difference, $p$ value was not given in the text.

\section{Results}

We have evaluated 7300 PET reports of 6803 patients and detected ED in $174 \mathrm{PET} / \mathrm{CT}$ scans of 131 patients. Forty-three these were single or multiple follow-up scans. Follow-up scans were performed for treatment response evaluation and/or restaging. Ninety-seven of these 131 patients were female (74\%) and 34 were male (26\%). The mean age was $62.13 \pm 8.6$ years. One hundred and sixty-five of the scans were performed for oncological purposes (94.8\%), while nine of them (5.2\%; three cardiac viability assessment and six other benign diseases) were performed for other purposes.

Prevalence of ED was 1.92\%. One hundred and sixteen patients (88.5\%) had bilateral and 15 patients (11.5\%) had unilateral ED, more dominant on the right side (12 on right; three on left). The mean diameters were $4.9 \times 2.4 \pm 1.1 \times 1.9 \mathrm{~cm}$, and mean SUV ${ }_{\max }$ value for FDG PET was $2.46 \pm 0.74$. There was a weak positive correlation between SUV ${ }_{\max }$ values and diameters $(p=0.05)$. The SUV $\mathrm{max}_{\text {max }}$ value $\left(\mathrm{SUV}_{\max }: 4.21\right)$ for single Ga-68 DOTATATE scans was not taken into account, as its uptake mechanism is different from FDG and shows SSTRs instead of metabolism. On visual assessment, radiopharmaceutical uptake of ED was similar to or minimally higher than the mediastinal intravascular uptake in most of the cases (168 out of 174). In six scans, uptakes were higher than the mediastinal intravascular uptake; but uptake was lower than the mediastinal intravascular uptake in none of the scans.

In the follow-up scan group, there was no statistically difference in terms of size and SUV $\mathrm{V}_{\max }$ value changes between initial and follow-up scans. The characteristic of patients and descriptive numbers are summarized in Table 1.

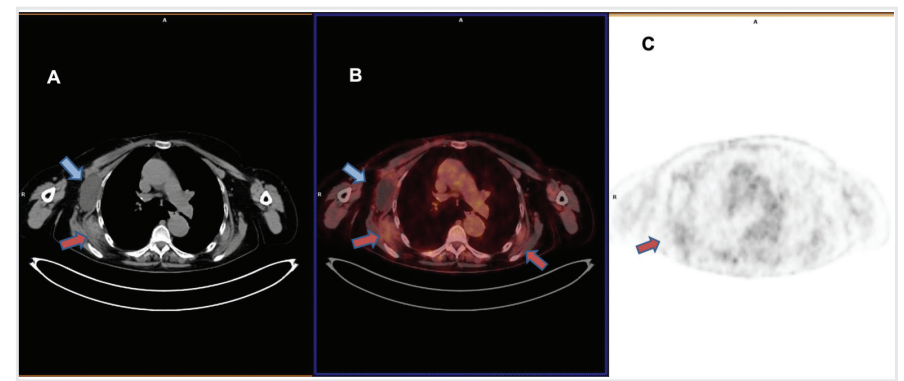

Figure 1. Axial slices of computed tomography (CT) (A), F-18 fluorodeoxyglucose (FDG) positron emission tomography (PET)/CT fusion (B) and F-18 FDG PET (C) images of a 64-year-old woman who was operated from right breast and axilla three weeks before PET/CT examination. Bilateral elastofibroma dorsi (EDs) (brown arrows) are noted; slightly larger on the right side. The largest one is measuring $2.8 \times 3.9 \mathrm{~cm}$ and SUV ${ }_{\text {max }}$ was 3.12. Postoperative seroma (blue arrow) is noted just anterior of the right $\mathrm{ED}$, due to recent axillar lymphadenectomy

\section{Discussion}

ED is a benign, soft tissue mass lesion located mostly at subscapulary region and it was first described in 1961 (1). It is characterized by the proliferation of elastin fibers in a stroma of collagen and adipose connective tissue. Although it may be diagnosed with various imaging modalities such as CT, MRI or even ultrasonography, diagnosis can be challenging in some cases with PET/CT in case of history of previous thoracic surgery, lymphomas, sarcomas etc.

Although the prevalence of ED was reported to differ between autopsy series (17\%) (3) and imaging modalities (1.6 to $2 \%$ for CT and $1.7 \%$ for PET-CT) (9-11), ED detection rate in our study (1.92\%) is similar with the reported $\mathrm{CT}$ and $\mathrm{PET} / \mathrm{CT}$ literature. It is well known that $\mathrm{ED}$ is more seen in elderly people (fifth and seventh decades of life) and females, and we found similar results in our study found (mean age: $62.13 \pm 8.6$ years and $74 \%$ female dominance) (4,9-12).

Although it has been reported that ED can be seen in various locations, other than subscapular region (1\%) (5-7), we have observed ED only at subscapular region in our series. Various numbers have been reported in the literature regarding the location and bilaterality of ED (58\%-85.5\%) (9-13). Similar to the literature, we detected bilateral localization of ED in $88.5 \%$ of patients (Figure 2). Similar to the reported numbers, we have found a right-sided dominance in unilateral cases (80\% vs $20 \%)(9,10)$. Slightly larger ED was noted on the right side in case of bilateralism; however, no statistically significant difference was observed. Various studies have reported the mean diameters of ED in a range between $2.0 \times 1.2 \mathrm{~cm}$ to $14 \times 13 \mathrm{~cm}$ with a huge variability, and our results $(2.6 \times 4.9 \pm 1.1 \times 1.9 \mathrm{~cm})$ are consistent with most of the studies in the literature $(4,8-15)$.

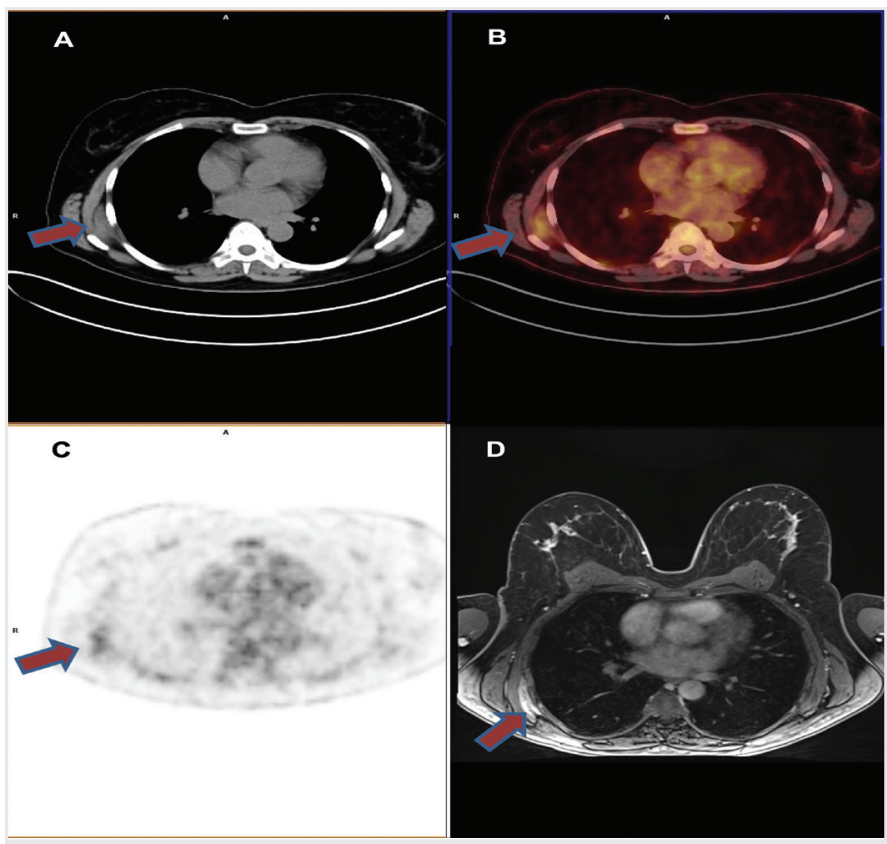

Figure 2. Axial slices of computed tomography (A), fusion (B), F-18 fluorodeoxyglucose(FDG) positron emission tomography (C) and T1-weighted magnetic resonance image (MRI) after contrast agent administration (D) in a 51-year-old woman with right sided breast carcinoma. Right sided, unilateral soft tissue lesion (arrows) measuring $2.4 \times 3.2 \mathrm{~mm}$ and shows increased FDG uptake (SUV max $: 3.31$ ) is noted. Well-differentiated unilateral soft tissue lesion with enhancement is noted on MRI 
In the literature, several studies have declared the strong and weak aspects of PET/CT imaging for ED, especially for F-18 FDG $(10,11,13,14)$. However, they all agree that PET/CT is not the tool for the diagnosis of ED. Instead of being a diagnostic tool for ED, interpretation of $\mathrm{PET} / \mathrm{CT}$ findings is important to avoid misdiagnosis and unnecessary interventions.

Different studies have reported various results for measured mean SUV $_{\max }$ values for F-18 FGD PET. Erhamamci et al. (10) reported SUV max $_{\text {ax }}$ as $2.31 \pm 0.61$ (range: 1.0 to 4.3), Blumenkrantz et al. (11) as 2.1 (range: 1.43.2), and Onishi et al. (14) as 2.0 0.63 (range: 0-5.1) (13). In our study, we found similar results with the literature $\left(S_{U} V_{\max } 2.46 \pm 0.74\right.$; range: 1.184.97). There are some studies and case reports reporting higher SUV ${ }_{\max }$ values, such as SUV ${ }_{\text {max }}$ equal to 3.2 (up to 4.7$)(11,13,15)$, which might be tricky if the interpreter just gives moderately high SUV $\mathrm{max}_{\max }$ value, instead of a more specific diagnosis. The exact mechanism of FDG uptake in ED is unknown, but anticipated as a combination of high vascularity and increased metabolic activity within the mass $(14,17)$.

Various studies showed uptake of different radiopharmaceuticals in ED, other than F-18 FDG; such as I-131, F-18 PSMA and Ga-68 DOTATATE, which is a SSTR agonist (18-21). In our study, all procedures, except one, were performed with F-18 FDG. Only one patient's ED was demonstrated with Ga-68 DOTATATE (Figure 3). Ga-68 DOTATATE is a radiolabeled SSTR analogue showing high affinity to SSTR type 2 , but it can bind with varying affinity to the other SSTRs. Somatostatin is an endogenous cyclic tetradecapeptide hormone. Primarily inhibitory in nature, this small

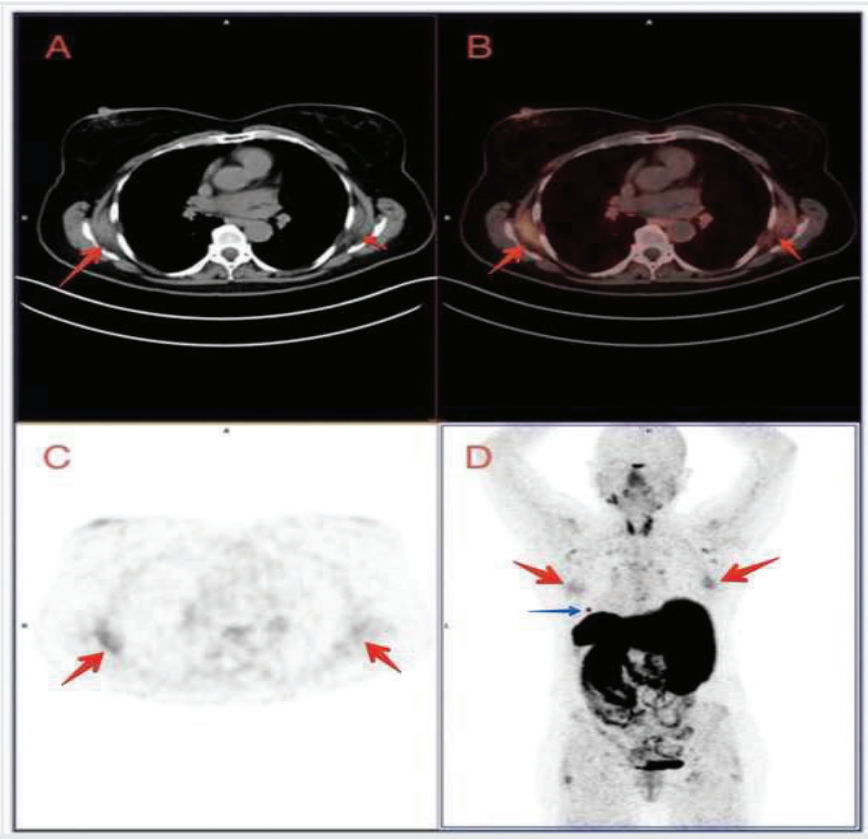

Figure 3. Axial slices of computed tomography (CT) (A), fusion (B), positron emission tomography (PET) (C) and posterior projection of MIP (D) images of a 59-year-old woman with Ga-68 DOTATATE PET/CT examination who was operated for rectal neuroendocrine neoplasia. Ga-68 DOTATATE PET/ $\mathrm{CT}$ revealed poorly circumscribed, soft-tissue lesions with minimally fat strands (A) and showing increased STTR expression (B and C), correspondent with elastofibroma dorsi. Right-sided ED is slightly larger than the left one and measures $28 \times 42 \mathrm{~mm}$ and SUV ${ }_{\max }$ value was 4.21. Also, focal Ga68 DOTATATE uptake corresponding with accessory spleen (blue arrow) is noted on MIP image peptide has anti-secretory and anti-proliferative effects and functions as a neurotransmitter. SST binds to five subtypes of G-protein-coupled transmembrane receptors (SSTR 1-5). SSTRs are widely expressed in normal tissues as well as malignant and inflammatory situations. Various studies have searched the immunohistochemical staining status of ED, and expression of vimentin, factor XIIIa and CD34 were detected with negative for smooth muscle actin, S-100, desmin, and p53 $(22,23)$. To our knowledge, there is no study histopathologically investigating SSTR expression in ED. According to our knowledge, following the case report by Ishiyama et al. (21), this is the second case showing STTR expression with Ga-68 DOTATATE PET/CT in ED.

The detection rate of benign lesions increases with increasing exponential use of $\mathrm{PET} / \mathrm{CT}$ in daily practice. Although the characteristics of ED are well described for CT and FDG PET/CT, the mechanism of low to mild FDG uptake is unclear. Various speculations can be made such as increased vascularity, reactive and inflammatory processes. However, according to our knowledge, no confirmative studies were conducted. In most of the ED cases, tissue sampling for diagnosis is not necessary; however, in some challenging cases, various imaging modalities or even surgical resection might be needed, especially in thoracic malignancies with previous surgical intervention.

\section{Study Limitations}

Our retrospective study has limitations such as lack of histological confirmation, but lesions remained similar on follow-up images or had fully benign appearance. Contrast-enhancement was not observed in CT scans and no routine and detailed clinical questionnaire were given for ED diagnosis.

\section{Conclusion}

Although PET/CT imaging is not the recommended tool for the diagnosis of ED; knowing the typical features and recognition of uptake patterns of PET radiopharmaceuticals are important for the nuclear medicine specialists and also for the refereeing clinicians, especially for the oncological patients with unilateral lesions or lesions with asymmetrical intense radiopharmaceutical uptake.

\section{Ethics Committee Approval: Retrospective study.}

Informed Consent: Retrospective study.

Peer-review: Internally peer-reviewed.

Financial Disclosure: The authors declared that this study received no financial support

\section{References}

1. Jarvi O, Saxen E. Elastofibroma dorse. Acta Pathol Microbiol Scand Suppl 1961; 51: $83-4$.

2. Hisaoka M, Hashimoto H. Elastofibroma. Clonal fibrous proliferation with predominant CD34-positive cells. Virchows Arch 2006; 448: 195-9.

3. Järvi $\mathrm{OH}$, Länsimies $\mathrm{PH}$. Subclinical elastofibromas in the scapular region in an autopsy series. Acta Pathol Microbiol Scand A 1975;83:87-108.

4. Nagamine N, Nohara Y, Ito E. Elastofibroma in Okinawa. A clinicopathologic study of 170 cases. Cancer 1982; 50: 1794-805. 
5. Mazzocchi M, Martano A, Di Ronza S, Dodbiba E, Divona L, Scuderi N. Concomitant right subscapular and left olecranon elastofibroma followed by inversion of the lesions: Case report. Anticancer Res 2009; 29: 503-7.

6. Nishida A, Uetani M, Okimoto T, Hayashi K, Hirano T. Bilateral elastofibroma of the thighs with concomitant subscapular lesions. Skeletal Radiol 2003; 32: $116-8$.

7. Shimizu S, Yasui C, Tateno M, Sato H, Homma S, Hirano E, et al. Multiple elastofibromas. J Am Acad Dermatol 2004; 50: 126-9.

8. Kransdorf MJ, Meis JM, Montgomery E. Elastofibroma: MR and CT appearance with radiologic-pathologic correlation. AJR Am J Roentgenol 1992; 159: 575-9.

9. Brandser EA, Goree JC, El-Khoury GY. Elastofibroma dorsi: prevalence in an elderly patient population as revealed by CT. AJR Am J Roentgenol 1998; 171: 977-80.

10. Erhamamci S, Reyhan M, Nursal GN, Torun N, Yapar AF, Findikcioglu A, et al. Elastofibroma dorsi incidentally detected by (18)F-FDG PET/CT imaging. Ann Nucl Med 2015; 29: 420-5.

11. Blumenkrantz Y, Bruno GL, Gonzalez CJ, Namías M, Osorio AR, Parma P. Characterization of elastofibroma dorsi with (18)FDG PET/CT: A retrospective study. Rev Esp Med Nucl 2011; 30: 342-5.

12. El Hammoumi M, Qtaibi A, Arsalane A, El Oueriachi F, Kabiri el H. Elastofibroma dorsi: Clinicopathological analysis of 76 cases. Korean J Thorac Cardiovasc Surg 2014; 47: 111-6.

13. Patrikeos A, Breidahl W, Robins P. F-18 FDG uptake associated with elastofibroma dorsi. Clin Nucl Med 2005; 30: 617-8.

14. Onishi Y, Kitajima K, Senda M, Sakamoto S, Suzuki K, Maeda T, et al. FDG-PET/ CT imaging of elastofibroma dorsi. Skeletal Radiol 2011; 40: 849-53.
15. Martin SP, Gariani J, Viaud C. Unusual presentation of elastofibroma dorsi on 18F-FDG-PET/CT: A case report. Medicine (Baltimore) 2016; 95: e2832.

16. Battaglia M, Vanel D, Pollastri P, Balladelli A, Alberghini M, Staals EL, et al. Imaging patterns in elastofibroma dorsi. Eur J Radiol 2009; 72: 16-21.

17. Shick S, Zembsch A, Gahleitner A, Wanderbaldinger P, Amann G, Breitenseher $M$, et al. Atypical appearance of elastofibroma dorsi on MRI: case reports and review of the literature. J Comput Assist Tomogr 2000; 24: 288-92.

18. Davidson T, Goshen E, Eshed I, Goldstein J, Chikman B, Ben-Haim S. Incidental detection of elastofibroma dorsi on PET-CT: Initial findings and changes in tumor size and standardized uptake value on serial scans. Nucl Med Commun 2016; 37: 837-42.

19. Oporto M, Cepa F, Orta N, Rubí S, Navalón H, Peña C. Fibroelastic pseudotumour elastofibroma dorsi detected by 18F-FDG PET/CT and by posttherapy radioiodine SPECT/CT. Rev Esp Med Nucl Imagen Mol 2018; 37: 46-9.

20. Gorin MA, Marashdeh W, Ross AE, Allaf ME, Pienta KJ, Pomper MG, et al. Uptake of the prostate-specific membrane antigen-targeted PET radiotracer 18F-DCFPyL in elastofibroma dorsi. Nucl Med Commun 2017; 38: 795-8.

21. Ishiyama M, Vesselle H. 68Ga DOTATATE PET/CT Imaging of elastofibroma dorsi. Clin Nucl Med 2018; 43: 154-5.

22. Kayaselçuk F, Demirhan B, Kayaselçuk U, Ozerdem OR, Tuncer I. Vimentin, smooth muscle actin, desmin, S-100 protein, p53, and estrogen receptor expression in elastofibroma and nodular fasciitis. Ann Diagn Pathol 2002; 6: 94-9.

23. Tasli F, Vardar E, Argon A, Kabat T, Deniz S, Nart A, et al. Histochemical and immunohistochemical characteristics of elastofibromas. Pol J Pathol 2014; 65: $120-4$ 